\title{
FORMATION OF THE COGNITIVE COMPONENT OF PROFESSIONAL IDENTITY OF FUTURE SPECIALISTS IN PHYSICAL THERAPY, ERGOTHERAPY
}

The aim of the article is to investigate the peculiarities of the formation of the cognitive component of the professional identity of future specialists in physical therapy, ergotherapy and to diagnose the developed system. Cognitive dispositional direction is provided with forms of education: lectures, seminars, discussions, observation of teachers' work during practice, independent work with scientific literature, preparation of reports. Its purpose is to form a cognitive component of professional identity to create the image of a professional, professional awareness. Formation of the cognitive component of professional identity of future specialists in physical therapy, ergotherapy in higher education, methodological approaches (acmeological, epistemological, personal, activity, axiological, synergetic and praxeological orientations) and principles, continuity and continuity, unity. Diagnosis of the cognitive component of the professional identity of future specialists in physical therapy, ergotherapy in the study, we conducted on the basis of cognitive criteria. Indicators and levels of the cognitive component are characterized. It is established that the cognitive criterion of formation of professional identity of future specialists in physical therapy, ergotherapy reflects the degree of theoretical awareness of the future specialist in the field of professional activity. Indicators of the cognitive criterion of formation of professional identity of future specialists in physical therapy, ergotherapy are completeness, depth and scientific knowledge of their professional rights and responsibilities, principles of evidence-based practice, modern methods of information retrieval, work with library and information resources, features of methods and means of physical therapy, ergotherapy. The conducted pedagogical experiment allowed to establish that the chosen methodical approaches and principles allow to provide formation of a cognitive component of professional identity of future experts in physical therapy, ergotherapy in higher educational institutions.

Key words: cognitive component, professional identity, future specialists, professional training, physical therapy, ergotherapy.

Formulation of the problem. Today the domestic system of professional education of specialists in physical therapy and ergotherapy where modernization processes are taking place, is a question of professional competence of graduates of higher education institutions. The ability of a physical therapist / ergotherapist to find his place in the professional space is determined by his readiness for independent professional activity and willingness to quickly navigate in the modern multidisciplinary space, constantly selfimprovement, critically considering their professional development and contribution to health care.

In such circumstances, the main result of higher education institutions that train specialists in physical therapy and ergotherapy is the possibility of comprehensive assignment of graduates of basic cultural and professional competencies, in which the willingness and ability to solve standard problems of professional activity in interaction is important among professional education [2].

Analysis of recent researches and publications. According to the results of analysis of recent research and publications, it is established that the cognitive component of professional identity reflects the assessment and self-assessment of cognitive abilities as a future professional, includes intrinsic motivation of cognitive interest in mastering professional knowledge, skills, professional competences, professional self-awareness profession in general $[1 ; 5]$. The criterion of this component is the consciousness and awareness of the professional activity.

Purpose of the article. The aim of the article is to investigate the peculiarities of the formation of the cognitive component of the professional identity of future specialists in physical therapy, ergotherapy and to diagnose the developed system.

Presentation of the main research material. Cognitive dispositional direction is provided with forms of education: lectures, seminars, discussions, observation of teachers' work during practice, independent work with scientific literature, preparation of reports. Its purpose is to form a cognitive component of professional identity to create the image of a professional, professional awareness. The cognitive component is based on independent educational and cognitive activities on the following grounds: 
- professional training of the future specialist takes into account the national and world experience of organizing independent educational and cognitive activities in order to increase the professionalism and personal development of the future teacher;

- independent educational and cognitive activity is considered not only as a system-forming didactic factor, common for subjects of education in higher and secondary educational institutions, and as a means of self-education in terms of professional activity;

- independent educational and cognitive activity of students of pedagogical educational institutions is a necessary condition for preparing future teachers for the organization of independent educational activities of students [3].

The cognitive component of professional identity is the formation of the amount of professionally significant knowledge and skills, is performs an information function. The analysis of the main didactic functions makes it possible to distinguish among this amount of knowledge the following types: information about the environment (ideas about the nature and properties of objects and phenomena of the surrounding reality); forms and methods of practical-cognitive activity (rules, norms, the order of development of abilities and skills); attitude to various environmental phenomena and the relationship between them, including the values of social groups and society in general [4].

The cognitive component helps in the formation and development of cognitive activity, activates the skills and abilities to form a willingness to work in the information society, which involves awareness of future professionals in the process of informatization of education, which is one of the areas of informatization. The cognitive component is characterized by the depth of mastery of knowledge, the ability to apply them to achieve professional goals. Due to the influence of the cognitive component in the process of development of cognitive activity are formed: scientific and practical mastery of information processing skills; interest in cognitive work with educational objects; ability to generalize, analyze and adapt the acquired knowledge for application in the education system; ability to navigate in prospects, plan professional activities and evaluate its results.

Formation of cognitive component of professional identity of future specialists in physical therapy, ergotherapy in higher education institutions, methodological approaches (acmeological, epistemological, personal, activity, axiological, synergetic and praxeological) and principles, continuity of orientation and differentiation).

The principle of professional orientation reflects the training of specialists in physical therapy, ergotherapy for professional activities, in which a set of knowledge, skills and abilities allows to perform activities to determine and improve quality of life and motor potential, in promoting healthy lifestyles, prevention, treatment / intervention, habilitation and rehabilitation. Further professional training is improved in the process of labor activity through the system of advanced training and self-education. This principle of professional orientation reflects the construction of a system of professional training of specialists in physical therapy and ergotherapy, taking into account the types of professional activities: comprehensive examination / assessment of an individual patient / client or the needs of a group of clients; evaluation of the results obtained during the examination / evaluation for making clinical decisions concerning patients / clients; diagnosis, prognosis and development of an intervention plan; providing advice within its competence and determining when exactly patients / clients should turn to other specialists; implementation of the intervention / treatment program; determining the results of any intervention / treatment; providing recommendations for independent work.

The principle of systematicity is a classic principle of didactics and is based on the following scientific principles: all actions on a person are effective only when they are purposeful and carried out in the system. Systematic means the orderliness of the knowledge system as the content of learning. In addition, each subject has its own scientific logic, its own system of concepts that follow from each other; each subject has its own patterns that reflect certain facts and phenomena. The principle of systematicity is associated with the laws of cognitive and practical activities of students. Material is considered mastered if a person has formed a system of associations and connections between old, acquired knowledge and new. At the same time, systematic thinking as a characteristic of a developed mind means that the human brain works more efficiently if it receives a load regularly, systematically and in certain portions.

Systematicity also means the need to establish links between topics and sections of the discipline, to establish interdisciplinary links, as each student is taught not one discipline, but several. This will contribute to a holistic view of the studied subjects, understanding the relationship and interdependence of various objects and phenomena. Also, this principle reflects the procedural side of learning, which must be built in a certain system. Training of a specialist in physical therapy, ergotherapy as a managed systematized process requires planning and is carried out in accordance with the developed program-methodical materials, which determines the system of the teacher's work in the process of professional training and allows to structure educational material. Systematization should also be manifested in the organization of the learning process, in the requirements for students in 
the system of each lesson. Systematic should be in the work of the student, manifested in the systematic preparation for classes, work in the classroom.

The principle of continuity and continuity reflects the length of the training process over time, its structure and stage nature. This principle also expresses the temporal and spatial connection of the stages of professional training of future specialists in physical therapy and ergotherapy. Continuity means building a training system from the beginning of vocational training. The course of professional training is realized as a progressive movement aimed at mastering new knowledge in certain disciplines and on the basis of interdisciplinary links, to build a system of practical training that allows to master professional skills, technologies and form professionally significant personality traits of the future specialist. The mechanism of continuity in training is continuity, which involves the preservation at each stage of training of basic knowledge, basic skills and personality traits, formed earlier in the previous stages.

The principle of unity of individualization and differentiation is considered in pedagogical science as connected with the account of age and individual features. Within its framework, "individualization" is seen as taking into account the individual characteristics of each individual, as each person is a unique individual, which is determined by the unity and integrity of each person's development. Each person has their own needs, their own individual inclinations, aptitudes and abilities. Hence, the approach to the student should be implemented taking into account his individual characteristics. On the other hand, individualization may not correlate with the need to take into account the individual characteristics of each, but to assume a certain differentiation, as it is difficult to fully individualize the training process.

Cognitive criterion of formation of professional identity of future specialists in physical therapy, ergotherapy reflects the degree of theoretical awareness of the future specialist in the field of professional activity.

Indicators of the cognitive criterion of formation of professional identity of future specialists in physical therapy, ergotherapy are completeness, depth and scientific knowledge of their professional rights and responsibilities, principles of evidencebased practice, modern methods of information retrieval, work with library and information resources, features of methods and means of physical therapy, ergotherapy.

The basic level of formation of professional identity of future specialists in physical therapy, ergotherapy by cognitive criteria is characterized by the presence of students' ideas about their professional rights and responsibilities; lack of understanding of the principles of scientific and evidence-based practice, modern methods of information retrieval, work with library and information resources; acceptance of features of use of methods and means of physical therapy, ergotherapy.

The advanced level of formation of professional identity of future specialists in physical therapy, ergotherapy by cognitive criteria is characterized by understanding and acceptance by students of their professional rights and responsibilities; expressed understanding of the principles of scientific evidencebased practice, modern methods of information retrieval, work with library and information resources; acceptance of features of use of methods and means of physical therapy, ergotherapy.

The highest level of professional identity of future specialists in physical therapy, ergotherapy by cognitive criteria is characterized by completeness, depth of knowledge of students about their professional rights and responsibilities; pronounced understanding of the principles of scientific and evidence-based practice, modern methods of information retrieval, work with library and information resources; understanding and acceptance of the peculiarities of the use of methods and means of physical therapy, ergotherapy.

The pedagogical experiment was attended by 131 students of the Academician Yuriy Bugay International Scientific and Technical University, Poltava Institute of Business Academician Yuriy Bugay International Scientific and Technical University, National Technical University of Ukraine “I. Sikorsky Kyiv Polytechnic Institute", which were classified as experimental and groups.

As a result of the pedagogical experiment it was found that the data characterizing the formation of professional identity of future specialists in physical therapy, ergotherapy increased in the experimental group from $41 \pm 2$ to $63 \pm 34$ and in the control group from $42 \pm 4$ to $44 \pm 18$. According to the diagnostic results After the pedagogical experiment, a difference was revealed between the indicators of future specialists in physical therapy, ergotherapy of experimental $(63 \pm 34)$ and control $(44 \pm 18)$ groups, which characterize the formation of professional identity.

It is important to note that before the pedagogical experiment, the majority of students, namely 54 students $(76,06 \%)$ of the experimental and 44 students $(73,33 \%)$ of the control groups, demonstrated that their professional identity by cognitive criteria is at a basic level. The advanced level of formation of professional identity was shown by the results of 17 students of the experimental and 16 students of the control groups, which is $23,94 \%$ and $26,67 \%$, respectively. The students of the experimental and control groups did not show the highest level of professional identity formation according to the cognitive criterion, which is $0 \%$. 
After the pedagogical experiment, the basic level of professional identity according to the cognitive criterion was demonstrated by 3 students of the experimental and 12 students of the control groups, which is $4,23 \%$ and $20 \%$, respectively. The advanced level of professional identity formation according to the cognitive criterion was demonstrated by 33 students of the experimental group and 34 students of the control group, which is $46,48 \%$ and $56,67 \%$, respectively. The highest level of professional identity formation by cognitive criterion was demonstrated by 35 students $(49,3 \%)$ of the experimental group and 14 students $(23,33 \%)$ of the control group.

According to the results of the analysis of the data of the pedagogical experiment we can state that the level of formation of the professional identity of future specialists in physical therapy, ergotherapy of the experimental and control groups according to the cognitive criterion has increased. This statement is confirmed by the fact that in the experimental group the number of students with the basic level of formation of professional identity by cognitive criterion decreased by $71,83 \%$, in the control - by $53,33 \%$; the number of students with advanced level increased in the experimental group by $22,54 \%$, in the control group by $30 \%$; the number of students whose professional identity is formed at the highest level increased in the experimental group by $49,3 \%$, in the control group by $23,33 \%$.

These indicators indicate the positive dynamics of the formation of professional identity in future specialists in physical therapy, ergotherapy by cognitive criteria, which took place during the pedagogical experiment.

Conclusions. Thestudysuggeststhattheformation of the cognitive component of the professional identity of future specialists in physical therapy, ergotherapy in higher education, methodological approaches (acmeological, epistemological, personal, activity, axiological, synergetic and praxeological orientations) and principles, principles, continuity, principles and differentiation). Diagnosis of the cognitive component of the professional identity of future specialists in physical therapy, ergotherapy in the study, we conducted on the basis of cognitive criteria. Indicators and levels of the cognitive component are characterized. It is established that the cognitive criterion of formation of professional identity of future specialists in physical therapy, ergotherapy reflects the degree of theoretical awareness of the future specialist in the field of professional activity. The conducted pedagogical experiment allowed to establish that the chosen methodical approaches and principles allow to provide formation of a cognitive component of professional identity of future experts in physical therapy, ergotherapy in higher educational institutions.

A promising issue for further research is the study of other parts of the system of formation of professional identity of future specialists in physical therapy, ergotherapy.

\section{References:}

1. Дмітрієва Н.С., Копочинська Ю.В. Формування професійної ідентичності майбутніх фахівців 3 фрізичної терапії як фрактор підвищення їх конкурентоспроможності. Збірник наукових праць «Педагогічнінауки». 2019.Вип. 79(3).С. 105-110. doi: 10.32999/ksu2413-1865/2019-87-19

2. Копочинська Ю.В. Деякі загальнонаукові підходи до формування професійної ідентичності майбутніх фрахівців із фізичної реабілітації. Збірник наукових праць «Педагогічні науки». Вип. LXXIX, том 3. C. 153-159.

3. Степанов Е.Н. В поисках более точного ответа. Личностно ориентированный подход. Директор школы. 2001. № 1. С. 71-75.

4. Стрельніков В.Ю. Критерії технологій навчання, орієнтованих на розвиток особистості. Нові технології навчання: наук.-метод, зб. Київ: Наук.-метод. иентр вищщї освіти. 2003. Вип. 35. С. 243-250.

5. Hammond R., Cross V., Moore A. The construction of professional identity by physiotherapists: A qualitative study. Physiotherapy. 2016. № 102, P. 71-77. doi:10.1016/j.physio. 2015.04.002

Копочинська Ю. В. Формування когнітивного компоненту професійної ідентичності майбутніх фахівців з фрізичної терапії, ерготерапії

Метою статmі є дослідити особливості формування когнітивного компонента профресійної ідентичності майбутніх фрахівців з фрізичної терапії, ерготерапії та діагностувати розроблену систему. Когнітивно-диспозиційний напрям забезпечений фрормами навчання: лекціями, семінарськими заняттями, дискусіями, спостереженням за роботою вчителів під час практики, самостійною роботою з науковою літературою, підготовкою доповідей. Його мета - сформувати пізнавальний компонент профресійної ідентичності для створення образу профресіонала, професійної поінформованості. Формування когнітивного компонента професійної ідентичності майбутніх фахівців з фрізичної терапії, ерготерапії у закладі вищої освіти, методологічних підходів (акмеологічних, гносеологічних, особистісних, діяльнісних, аксіологічних, синергетичних та праксеологічних орієнтацій) та принципи, наступність та наступність, єдність індивідуалізації та дифреренціації). Діагностику когнітивного складника профресійної ідентичності майбутніх фахівців з фрізичної терапії, ерготерапії у дослідженні ми проводили на основі когнітивного крите- 
рію. Охарактеризовано показники та рівні когнітивного складника. Встановлено, що когнітивний критерій сформованості профресійної ідентичності майбутніх фрахівців з фрізичної терапії, ерготерапії відображає ступінь теоретичної обізнаності майбутнього фрахівия у сфері профресійної діяльності. Показниками когнітивного критерію сформованості профресійної ідентичності майбутніх фрахівців з фрізичної терапії, ерготерапії є повнота, глибина та науковість знань щодо своїх профресійних прав та обов'язків, принципів науково-доказової практики, сучасних методів пошуку інфоормації, роботи з бібліотечними та інформаційними ресурсами, особливостей використання методів і засобів фрізичної терапії, ерготерапії. Проведений педагогічний експеримент дозволив встановити, що обрані методичні підходи та принципи дозволяють забезпечити фрормування когнітивного компонента профресійної ідентичності майбутніх фрахівців з фізичної терапії, ерготерапії у вищих навчальних закладах.

Ключові слова: когнітивний компонент, профресійна ідентичність, майбутні фрахівці, професійна підготовка, фрізична терапія, ерготерапія. 